\title{
Pengaruh patronage buying motives terhadap prinsip going concern pada UMKM
}

\author{
Chalarce Totanan* \\ *Universitas Tadulako, chalarce@untad.ac.id, Palu, Indonesia
}

\section{ARTICLE INFO \\ Article history: \\ Received 10 April 2018 \\ Received I Revised 30 Juli \\ 2018 \\ Accepted 4 Agustus 2018}

Keywords:

Patronage Buying

Motives, Going

Concern, SMEs

Onion Fried

\section{A B S T R A C T}

This article aims to analyze the influence of patronage buying motives namely of company location, production facility, price, and product quality on going concern principle on UMKM of fried onion in Palu. Respondents in the study were owners or managers of UMKM fried onion industries in Palu, Population 52 based on data from the Industry and Trade Office, but only 40 were active. Data obtained through questionnaires and interviews, processed by SPSS program. Data analysis was done by multiple linear regression. The results revealed that the location of the company and the price did to singificantly affect the going concern principle. Going concern principle on UMKM business operators due to production and product quality

Artikel ini bertujuan untuk menganalisis pengaruh patronage buying motives yang terdiri dari letak perusahaan, fasilitas produksi, harga, dan kualitas produk terhadap prinsip going concern pada UMKM bawang goreng di Kota Palu. Responden dalam penelitian adalah pemilik atau pengelola industri rumah tangga bawang goreng di Kota Palu yang berjumlah 52 berdasarkan data Dinas Perindustrian dan Perdagangan, namun hanya 40 yang aktif. Data diperoleh melalui kuisioner dan wawancara, diolah menggunakan program SPSS. Analisis data dilakukan dengan regresi linear berganda. Hasil penelitian mengungkapkan bahwa lokasi perusahaan dan harga tidak berpengaruh sigifikan terhadap prinsip going concern. Prinsip going concern pada pelaku usaha UMKM diakibatkan oleh produksi dan kualitas produk. 
The power of small..."karena bergerak dari kecil, kami harus melihat sesuatu secara lebih detail" kata Huliselan general marketing BrunBrun Paris (Bachdar, 2018). Kesadaran perlunya mengembangkan industri kecil mulai disadari setelah terjadinya krisis moneter pada tahun 1997 yang menyebabkan likuidasi dan pemutusan hubungan kerja yang besar di Indonesia. Hal ini menyebabkan terjadinya krisis moneter. Namun muncul fenomena setelah melihat kenyataan bahwa perusahaan besar dengan modal yang besar ternyata tidak setangguh perusahaan kecil dalam menghadapi krisis ekonomi. Seperti pada tahun 2017, perusahaan-perusahaan peritel besar satu persatu mengalami kesulitan karena penjualan yang rendah dan mengakibatkan masalah keuangan karena gagal dalam merespon dinamika pasar.

Berbeda dengan perusahaan kecil yang mampu bertahan dan terus berproduksi. Tidak mengherankan jika pemerintah kemudian mendorong perkembangan usaha kecil dan menengah dengan berbagai program, seperti kredit usaha rakyat (KUR) dengan bunga yang lebih rendah. Hal ini dimaksudkan oleh pemerintah untuk menggerakkan sektor industri kecil agar bisa berkembang dan membuka lapangan kerja.

Ambisi menteri Koperasi dan Usaha Kecil Menengah (UKM) untuk menggerakkan Koperasi dan UKM agar menyumbang 5\% PDB (Pendapatan Domestik Bruto) (Tempo.co, 2017) cukup beralasan. Hal ini didukung data Metrotvnews.com, 7 juni 2017 bahwa kontribusi UMKM terhadap Produk Domestik Bruto (PDB) telah mencapai 61\%. Angka ini disumbang oleh usaha mikro 30,3\%, usaha kecil $12,8 \%$, dan usaha menengah 14,5\%. Sedangkan kontribusi koperasi terhadap PDB telah mencapai sekitar 23,12\%. Hal ini bisa dicapai dengan jumlah penggiat UMKM yang telah mencapai sekitar 57 juta orang. Meskipun potensi UMKM cukup besar dengan pertumbuhan 6,56\% ditahun 2016, namun kontribusinya terhadap ekspor nasional masih berada pada kisaran 15,7\%. Jika dibandingkan dengan Vietnam 17\%, dan Thailand pada angka 35\% Indonesia masih tertinggal. Badan Pusat Statistik (BPS) per Agustus 2017 bahwa pertumbuhan produksi mikro dan kecil di kuartal II-2017 sebesar 2,5\% turun dari kuartal I-2017 sebesar 6,63\%. Target pertumbuhan ekonomi tahun 2018 yang dicanangkan pemerintah pada kisaran 5,4\% akan sulit tercapai jika kontribusi UMKM rendah.

Kota Palu sebagai salah satu provinsi dengan tingkat pertumbuhan yang tinggi di Indonesia memiliki produk unggulan berupa bawang goreng Palu. Tanaman ini merupakan varietas endemik yang ada di Lembah Palu. Sampai saat ini bawang goreng ini masih sebatas diproduksi oleh industri rumah tangga dan dijadikan sebagai sovenir bagi wisatawan yang berkunjung ke Palu. Dari data Dinas Perindustrian dan Perdagangan ada 52 UMKM yang memproduksi bawang goreng. Tetapi jumlah ini terus berfluktuasi karena tidak mampu untuk bersaing dan mempertahankan eksistensinya. Ini berarti bahwa UMKM bawang goreng Palu ini belum going concern atau sustainability. Jika sebuah perusahaan going concern berarti perusahaan tersebut eksis beroperasi. Menurut Finney dan Miller (1959), going concern as an established business that is being conducted with the expectation of continuing indefinitely.

Going concern merupakan konsep akuntansi dan menjadi sebuah postulat, sebuah prinsip bahwa perusahaan tidak akan dilikuidasi atau dibubarkan. Going concern adalah prinsip alamiah setiap entitas termasuk manusia yang ingin tetap survive dan tidak akan mati. Sehingga, konsep going concern dianggap lebih penting bagi usaha kecil dibandingkan dengan usaha besar dan mapan. Meskipun karakterisitik perusahaan, pengaruh politik dan kondisi keuangan juga berpengaruh terhadap prinsip ini (Mapparessa, dkk, 2017).

Going concern hanya bisa dicapai melalui perjuangan agar hidup berkelanjutan. Bagi perusahaan kecil hal ini bisa diperoleh melalui peningkatan penjualan hasil produksi dari usaha tersebut. Untuk mencapai hal tersebut usaha kecil dan menengah, khususnya usaha rumahan bawang goreng Palu 
memerlukan analisa dari patronage buying motives sebagai variabel yang memengaruhi prinsip going concern terhadap UMKM bawang goreng.

Patronage buying motives merupakan variabel yang berhubungan motivasi dari konsumen terhadap hasil produksi sebuah usaha. Motivasi ini bisa berupa rasa ingin membeli atau memakai sebuah produk. Hasil produksi yang diminati oleh konsumen bisa menjadi indikator going concern bagi usaha

tersebut. Perubahan selera konsumen yang bervariasi akan menyebabkan perputaran laba lebih fluktuatif dan perputaran aktivanya juga akan berfluktuasi (Mahapsari \& Taman, 2013). Selain selera konsumen, perputaran laba dan perputaran aktiva persediaan, perubahan selera konsumen juga akan berpengaruh pada perubahan penjualan. Ketika penjualan meningkat secara langsung akan berpengaruh terhadap profitabilitas (Sari, dkk, 2013). Penelitian ini bertujuan mencari dan menganalisis pengaruh patronage buying motives terhadap going concern UMKM bawang goreng di Kota Palu.

Selain motif kebutuhan, alasan lain untuk membeli juga karena faktor-faktor seperti lingkungan, kebudayaan, strata sosial, perilaku keluarga, dan karena adanya referensi dari teman (Alma, 2009). Dari banyaknya faktor-faktor tersebut, faktor pribadi dan psikologis juga berpengaruh, seperti kemapanan, umur, pekerjaan, gaya hidup, kepribadian, dan konsep diri juga turut berpengaruh (Setiadi, 2003). Motif dan faktor-faktor tersebut merupakan unsur internal dan ekternal dari diri konsumen, sehingga tidak bisa juga diabaikan bahwa ada faktor-faktor yang berasal dari perusahaan. Faktor-faktor itulah yang terangkum dalam patronage buying motives, yaitu: harga, lokasi produksi, kualitas produk, dan fasilitas produksi. Faktor internal dan eksternal konsumen, serta faktor dari perusahaan akan bergabung dan memengaruhi konsumen dalam memutuskan untuk membeli sebuah produk. Menurut Kotler dan Armstrong (2001) proses keputusan membeli suatu produk oleh konsumen terdiri dari lima tahap, yaitu:

1. Pengenalan kebutuhan atau masalah

2. Pencarian informasi

3. Mengevaluasi berbagai alternatif yang ada

4. Keputusan membeli

5. Perilaku pasca pembelian

Berdasarkan pendapat Kotler \& Keller (2016), konsumen tidak akan berbelanja tanpa adanya motif, meskipun motif tersebut didorong oleh berbagai faktor yang saling berkaitan satu dengan lainnya. Motif membeli dari konsumen berhubungan secara langsung dengan penjualan perusahaan dan berujung pada peningkatan perofitabilitas. Motif membeli ini akan menjadi 'driver' perilaku yang akan membawa konsumen ke 'pasar' untuk memenuhi hasrat berbelanjanya (Jin \& Kim, 2003). Perusahaan yang berfokus pada patronage buying motives berarti akan berfokus pada konsumen dan menganggap konsumen adalah asset yang berharga. Karena tanpa konsumen tidak akan ada penjualan, dan tanpa penjualan tidak akan ada pendapatan. Hal ini berarti tidak akan ada profitabilitas.

Menurut Dinas Perdagangan dan Perindustrian Kota Palu, selama ini bawang goreng masih terbatas dijual pada tempat-tempat tertentu dengan informasi yang relatif terbatas bagi para konsumen dan khususnya wisatawan. Ini berarti bawang goreng belum merupakan produk 'wajib' untuk setiap konsumen lokal apalagi wisatawan. Sehingga diperlukan usaha yang lebih keras dari pihak-pihak yang berwenang untuk lebih mempopulerkan produk ini. Hal ini disadari karena selama ini promosi mengenai produk bawang goreng masih terbatas pada pameran yang dilakukan oleh pemerintah, sedangkan brosur, iklan di media massa ataupun media elektronik belum tersedia. Pada umumnya konsumen hanya mendapat informasi yang terbatas, misalnya dari kerabat, teman atau dari kenalannya yang pernah mengunjungi Palu atau yang pernah mengkonsumsinya secara langsung.

Kurangnya informasi produk bawang goreng ini menyebabkan para calon konsumen kesulitan membangkitkan motif membeli dan tidak bisa membandingkan alternatif produk yang ada. Oleh karena setiap konsumen punya gambaran dan motivasi kepuasan yang berbeda dalam memutuskan untuk 
membeli suatu produk. Hal ini secara tidak langsung berdampak pada berfluktuasinya permintaan terhadap produk bawang goreng Palu. Misalnya, penjualan akan meningkat ketika musim libur atau ketika hari raya keagamaan.

Fenomena memerlihatkan industri rumah tangga bawang goreng di kota Palu secara kuantitas cenderung memerlihatkan penurunan. Data Dinas Perindustrian dan Perdagangan Kota Palu, sebelum tahun 2017 jumlah perusahaan yang beroperasi sebanyak 25 perusahaan. Akan tetapi pada tahun 2017 menurut data dari Dinas Perdagangan dan Perindustrian ada peningkatan jumlah industri bawang goreng yang cukup signifikan yaitu sejumlah 52. Jumlah ini memerlihatkan bahwa ada pembentukan industri rumah tangga yang berdasarkan prinsip Going Concern (kontinuitas usaha) tetap berlaku. Prinsip going concern ini perlu diteliti karena dalam suatu industri rumah tangga karena walaupun industri ini masih dikategorikan sebagai industri kecil tapi mampu menjadi sumber penghasilan dan membuka lapangan kerja. Dari penelitian awal jumlah tenaga kerja yang terserap di sektor ini sebagai tenaga tetap sebanyak 116 orang tidak termasuk tenaga borongan.

Berdasarkan hasil pengamatan penulis di lapangan, upaya-upaya pemasaran yang dilakukan belum bisa memenuhi harapan para pengelola industri bawang goreng, walaupun lembaga-lembaga pembinaan yang ada telah berusaha membantu tetapi masih terbatas pada pengelolaan produk dan usaha, belum pada usaha pemasaran. Mengingat belum dikelolanya patronage buying motives secara profesional, perlu dilakukan suatu penelitian mengenai variabel patronage buying motives yang diprioritaskan pada pengelola dan pembina industri rumah tangga bawang goreng di kota Palu, sehingga kelangsungan hidup industri rumah tangga bawang goreng dikota palu dapat berjalan. Penelitian ini diharapkan dapat membantu untuk mengetahui perubahan-perubahan dan motif membeli konsumen terhadap bawang goreng sehingga industri rumah tangga bawang goreng ini dapat berkembang seperti industri rumah tangga makanan di propinsi yang lain dan yang utama bisa tetap eksis dalam persaingan dengan produk lain.

\section{METODE}

Penelitian ini merupakan survei dengan objek penelitian patronage buying motives yang terdiri dari: Lokasi penjualan, fasilitas produksi, harga produk, dan kualitas produk sebagai variabel independen, dan going concern sebagai variabel dependen. Indikator dari variabel penelitian tampak pada tabel 1 berikut:

Tabel 1

Indikator Variabel Penelitian

\begin{tabular}{|c|c|c|c|}
\hline Variabel & Konsep Variabel & Indikator & Skala \\
\hline Lokasi penjualan (X1) & Letak lokasi perusahaan & Kestrategisan lokasi dan Tata letak & Ordinal \\
\hline Fasilitas Produksi (X2) & Ketersediaan fasilitas untuk berproduksi & $\begin{array}{l}\text { Fasilitas memadai, fasilitas tekonologi yang } \\
\text { digunakan }\end{array}$ & Ordinal \\
\hline Harga (X3) & $\begin{array}{l}\text { Harga bawang goreng yang dijual di tempat } \\
\text { penjualan }\end{array}$ & $\begin{array}{l}\text { Variasi harga } \\
\text { Variasi kemasan }\end{array}$ & Ordinal \\
\hline Kualitas bawang goreng (X4) & Kualitas bawang goreng yang dijual & $\begin{array}{l}\text { Izin produksi, Daya tarik kemasan, kualitas } \\
\text { produk }\end{array}$ & Ordinal \\
\hline Prinsip Going Concern (Y) & $\begin{array}{l}\text { Perusahaan akan hidup terus dan tidak akan } \\
\text { dilikuidasi }\end{array}$ & $\begin{array}{l}\text { Modal, Sumber daya } \\
\text { Kontinuitas, Produksi, dan Penjualan }\end{array}$ & Ordinal \\
\hline
\end{tabular}

Penelitian ini dilakukan pada industri rumah tangga bawang goreng di Kota Palu. Populasi dari penelitian ini adalah 52 UMKM indsutri bawang goreng berdasarkan data dari Dinas Perdagangan dan Perindustrian tahun 2017. Data diperoleh melalui kuisioner dengan responden pengelola atau pemilik 
industri rumah tangga bawang goreng. Hasil kuisioner diolah dengan program SPPS dan uji analisis dengan menggunakan regresi linier berganda dengan persamaan:

$$
Y=\beta 0+\beta 1 X 1+\beta 2 X 2+\beta 3 X 3+\beta 4 X 4+\varepsilon
$$

Keterangan :

$\mathrm{Y}$ adalah going concern

ß0 adalah konstanta, yaitu nilai Y jika semua variabel $\mathrm{X}$ bernilai nol

B1 adalah koefisien regresi dari X1 (Lokasi Penjualan)

B2 adalah koefisien regresi dari X2 (Fasilitas Produksi)

B3 adalah koefisien regresi dari X3 (Harga Produk)

ß4 adalah koefisien regresi dari X4 (Kualitas Produk)

$\varepsilon$ adalah variabel lain yang tidak diuji

Variabel independen didasarkan pada Stanton, William J., Michael Etzel, (1997).

Hipotesis dari penelitian ini adalah: Lokasi penjualan, fasilitas produksi, harga produk, dan kualitas produk, masing-masing berpengaruh terhadap prinsip going concern berdasarkan pada konsep dalam akuntansi. Konseptual dan proses pengujian dilakukan berdasarkan pada gambar di bawah ini:

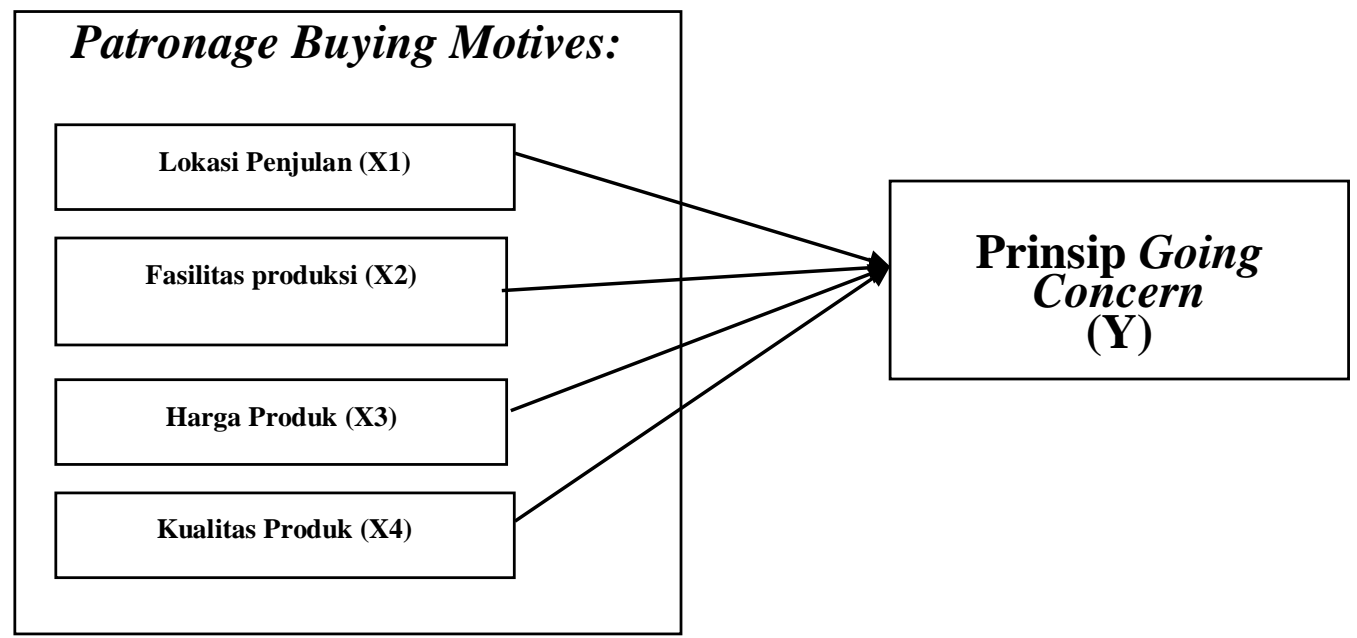

Gambar 1 Konseptual Penelitian

\section{HASIL DAN PEMBAHASAN}

\subsection{Hasil Uji Analisis Regresi Linier Berganda}

Dari persamaan 1 yang digunakan maka diperoleh hasil perhitungan bentuk hubungan fungsional antara varibel bebas dan variable terikat dengan menggunakan analisis regresi disajikan dalam tabel berikut: 
Tabel 2

Koefisien Regresi dan Uji Signifikansi

\begin{tabular}{|l|r|r|r|r|}
\hline Variabel Independen & \multicolumn{1}{|l|}{ Koefisien } & Std. Error & t-hitung & p-value \\
\hline Constant &,- 666 & 2,427 &,- 275 &, 786 \\
X1 (Letak lokasi penjualan) &, 130 &, 215 &, 602 &, 554 \\
X2 (Fasilitas produksi) &, 937 &, 246 & 3,803 &, 001 \\
X3 (Harga) &, 093 &, 288 &, 324 &, 749 \\
X4 (Kualitas produk) & 1,097 &, 287 & 3,829 &, 001 \\
\hline
\end{tabular}

Variabel Dependen: Prinsip Going Concern.

Berdasarkan hasil perhitungan seperti pada tabel 2, maka persamaan regresinya sebagai berikut:

$\hat{Y}=-0,666+0,130 X 1+0,937 X 2+0,093 X 3+1,097 X 4$

Model regresi tersebut menjelaskan bahwa apabila terjadi peningkatan penilaian terhadap letak lokasi penjualan sebesar satu satuan, maka prinsip going concern akan meningkat sebesar 0,130 jika variabel bebas yang lain $(\mathrm{x} 2, \mathrm{x} 3, \mathrm{x} 4)$ dianggap konstan atau tidak berubah. Perbaikan terhadap fasilitas produksi sebesar satu satuan, maka prinsip going concern akan meningkat sebesar 0,937 jika variabel bebas yang lain $(\mathrm{x} 1, \mathrm{x} 3, \mathrm{x} 4)$ dianggap konstan atau tidak berubah. Setiap perubahan penilaian terhadap harga menjadi lebih kompetitif sebesar satu satuan, maka prinsip going concern akan meningkat sebesar 0,093 jika variabel bebas yang lain $(\mathrm{x} 1, \mathrm{x} 2, \mathrm{x} 4)$ dianggap konstan atau tidak berubah. Selanjutnya untuk setiap peningkatan penilaian kualitas produk sebesar satu satuan, maka prinsip going concern akan meningkat sebesar 1,097 jika variabel bebas yang lain (x1, x2, x3) dianggap konstan atau tidak berubah.

\subsection{Hasil Uji t}

Pengujian ini dilakukan untuk menguji apakah hipotesis yang diajukan diterima atau ditolak. Hipotesis diterima atau ditolak dengan berpedoman pada Kriteria pengujian jika t-hitung $>$ t-tabel, maka hipotesis nol ditolak, dan sebaliknya jika t-hitung $<$ t-tabel berarti hipotesis diterima.

\section{Pengaruh Letak Lokasi Penjualan terhadap Prinsip Going Concern}

Secara teoritis letak lokasi penjualan berpengaruh terhadap prinsip going concern. Berdasarkan hasil perhitungan SPSS maka diperoleh nilai t-hitung sebesar 0,602 dan dari tabel student dengan $\alpha=$ 0,05 diperoleh nilai t-tabel $=1,7247$. Dari hasil tersebut ternyata t-hitung $<$ dari t-tabel, jadi hipotesis nol diterima. Ini berarti letak lokasi penjualan tidak berpengaruh terhadap prinsip going concern.

Hal ini bisa dihubungkan dengan variabel lain yang diteliti bahwa suatu produk yang berkualitas dengan tingkat kebutuhan dan kompetitif dalam harga, maka konsumen tetap akan mencari produk tersebut. Tetapi berdasarkan hasil perhitungan regresi ternyata letak lokasi penjualan tetap berpengaruh sebesar 0,130, yang berarti jika terjadi peningkatan kestrategisan letak lokasi penjualan sebesar 1 satuan maka akan meningkatkan prinsip going concern sebesar 0,130 kali jika varibel bebas lainnya konstan.

\section{Pengaruh Fasilitas Produksi terhadap Prinsip Going Concern}

Secara teoritis variabel fasilitas produksi berpengaruh terhadap prinsip going concern. Sehingga hipotesis alternatif adalah fasilitas produksi berpengaruh terhadap prinsip going concern. Berdasarkan hasil perhitungan SPSS maka diperoleh nilai t-hitung sebesar 3,803 dan dari tabel dengan $\alpha=0,05$ diperoleh nilai $\mathrm{t}$-tabel $=1,7247$. Dari hasil tersebut ternyata t-hitung $>$ dari $\mathrm{t}$-tabel, jadi hipotesis nol ditolak. Sehingga pada tingkat kepercayaan $95 \%$ hipotesis nol ditolak, artinya hipotesis fasilitas produksi 
berpengaruh terhadap prinsip going concern diterima. Nilai koefisien regresi yang diperoleh bertanda positif sebesar 0,937 yang menjelaskan bahwa jika terjadi peningkatan fasilitas produksi sebesar satu satuan maka prinsip going concern akan meningkat sebesar 0,937 kali jika variabel bebas lainnya konstan.

\section{Pengaruh Harga terhadap Prinsip Going Concern}

Secara teoritis variabel harga berpengaruh terhadap prinsip going concern. Sehingga hipotesis alternatif adalah harga berpengaruh terhadap prinsip going concern. Berdasarkan hasil perhitungan SPSS diperoleh nilai t-hitung sebesar 0,324 dan dari tabel $\alpha=0,05$ diperoleh nilai t-tabel $=1,7247$. Dari hasil tersebut ternyata t-hitung>dari t-tabel, jadi hipotesis nol diterima pada tingkat kepercayaan $95 \%$ dan hipotesis alternatif ditolak. Artinya harga tidak berpengaruh terhadap prinsip going concern. Nilai koefisien regresi yang diperoleh bertanda positif sebesar 0,093 yang menjelaskan bahwa jika terjadi peningkatan harga sebesar satu satuan maka prinsip going concern akan meningkat sebesar 0,093 kali jika variabel lain konstan.

\section{Pengaruh Kualitas Produk terhadap Prinsip Going Concern}

Secara teoritis variabel kualitas produk berpengaruh terhadap prinsip going concern. Sehingga hipotesis alternatif adalah fasilitas produksi berpengaruh terhadap prinsip going concern. Berdasarkan hasil perhitungan SPSS diperoleh nilai t-hitung sebesar 3,829 dan dari tabel dengan $\alpha=0,05$ diperoleh nilai $\mathrm{t}$-tabel $=1,7247$. Dari hasil tersebut ternyata t-hitung $>$ dari t-tabel, jadi hipotesis nol pada tingkat kepercayaan 95\% ditolak, dan hipotesis alternatif diterima. Dengan demikian kualitas produk berpengaruh terhadap prinsip going concern. Nilai koefisien regresi yang diperoleh bertanda positif sebesar 1,097 yang menjelaskan jika terjadi peningkatan fasilitas produksi sebesar satu satuan maka prinsip going concern akan meningkat sebesar 1,097 kali jika variabel bebas lainnya konstan.

\subsection{Koefisien Korelasi dan Koefisien Determinasi}

Besarnya kekuatan hubungan antara variabel independen dengan variabel dependen, dapat dilihat dari koefisien korelasi multipel (R). Besarnya kekuatan hubungan tersebut dapat diketahui dengan menggunakan perhitungan berikut ini:

$$
\mathrm{R}^{2}=\frac{\mathrm{JKregresi}}{\mathrm{JKtotal}}=\frac{1271,938}{1417,8351}=0,8971
$$

Ini berarti prinsip going concern dipengaruhi oleh patronage buying motives sebesar $89,71 \%$ sedangkan 10,29\% dipengaruhi oleh variabel lain. Kekuatan hubungan antara variabel bebas dan variabel terikat dilihat pada nilai R sebesar 0,947 yang berarti erat atau kuat. Berarti bahwa patronage buying motives mempunyai hubungan yang erat dengan prinsip going concern pada industri rumah tangga bawang goreng di kota Palu. Berdasarkan pembahasan yang telah dikemukakan di atas, maka apabila diurutkan masing-masing dari koefisien regresi yang paling tinggi adalah kualitas produk (X4) sebesar 3,829, kemudian fasilitas produksi (X2) sebesar 3,803, kemudian letak lokasi penjualan (X1) 0,602 dan terakhir harga (X3) sebesar 0,324. Hal ini menunjukkan bahwa kualitas produksi harus merupakan prioritas yang pertama untuk diperbaiki, kemudian fasilitas produksi, kemudian letak lokasi penjualan dan terakhir baru kemudian harga yang harus disesuaikan.

Oleh karena kulitas produksi unsur yang memunyai pengaruh paling besar harus diprioritaskan oleh pengelola industri rumah tangga bawang goreng di Kota Palu. Sehingga harus menjadi perhatian pertama, dan ini sejalan dengan fenomena tuntutan bisnis yang menuntut kualitas. Kualitas produk ini 
hanya dapat dicapai dengan perbaikan dan penyediaan fasilitas produksi. Kedua varibel tersebut akan mendukung variabel yang lain seperti letak lokasi penjualan dan harga.

\section{KESIMPULAN}

Patronage buying motives yang terdiri dari letak lokasi penjualan, fasilitas produksi, harga dan kualitas produk berpengaruh terhadap prinsip going concern, sehingga UMKM dan usaha kecil lainnya harus memperhatikan faktor-faktor tersebut, terutama kualitas dan fasilitas produksi harus menjadi fokus utama untuk bisa tetap survive. Keterbatasan dari penelitian ini adalah pada homogenisasi sumber data, yaitu hanya dari industri rumah tangga bawang goreng di Kota Palu. Penelitian selanjutnya bisa memperluas populasi pada semua jenis UMKM dan salam lingkup yang lebih luas lagi.

\section{DAFTAR PUSTAKA}

Arfan Ikhsan dan Muhammad Ishak, 2005, Akuntansi Keprilakuan, Jakarta, Salemba Empat

Basu Swastha dan T. Hani Handoko, 2000, Manajemen Pemasaran : analisa Perilaku Konsumen, Yogyakarta, BPFE.

Daniel, Wayne W., 1990, Applied Nonparametric, 2nd edition, Boston Massachusetts, PWS-KENT Publishing Company.

Donald, Kieso et al. 2001, Akuntansi Intermediate, $10^{\text {th }}$ Edition, Jakarta, Erlangga.

Gujarati, Damodar N., 2003, Basic Econometrics 4rth edition, New York. McGraw-Hill,

Myers, Raymond H., 1990, Classical And Modern Regression With Aplications, 2nd edition, Boston Massachusetts, PWS-KENT Publishing Company.

Nirwana K. Sitepu, 1994, Analisis Jalur, Bandung, Unit Pelayanan Statistika Universitas Pajajaran.

Porter, Michael E., 1994, Keunggulan Bersaing, Edisi Bahasa Indonesia, Jakarta Barat, Indonesia, Binarupa Aksara.

Saifuddin Azwar, 1997, Reliabilitas dan Validitas, Edisi ke-3, Yogyakarta, Pustaka Pelajar.

Schiffman, Leon G., and Leslie L. Kanuk, 2000, Consumer Behavior, USA, Prentice-Hall.

Srinutupang, Supoet S., 2003, Telecomunication System Design and Management : Marketing Promotional Strategy, melalui http://www.altavista.com.

Stanton, William J., Michael Etzel, and Bruce J. Walker, 1997, Fundamentals of Marketing. $10^{\text {th }}$ Edition, USA, McGraw-Hill International.

Stoner, James, R. Edward Freeman, Daniel Gilbert Jr, 1996. Management, $6^{\text {th }}$ Edition, New Jersey, Prentice Hall

Winardi, 1998, Kamus Ekonomi, Bandung, Penerbit Mandar Maju.

Zaki Baridwan, 2004, Intermediate Accounting, Edisi 8, Yogyakarta, BPFE 